\title{
Identification of Pyrogallol in the Ethyl Acetate-Soluble Part of Coffee as the Main Contributor to Its Xanthine Oxidase Inhibitory Activity
}

\section{Sari Honda and Toshiya Masuda}

\begin{tabular}{|c|l|}
\hline Citation & Journal of Agricultural and Food Chemistry, 64(41); 7743-7749 \\
\hline Issue Date & 2016-09-29 \\
\hline Type & Journal Article \\
\hline Textversion & Author \\
\hline Rights & $\begin{array}{l}\text { This document is the Accepted Manuscript version of a Published Work that appeared } \\
\text { in final form in Journal of Agricultural and Food Chemistry, copyright C American } \\
\text { Chemical Society after peer review and technical editing by the publisher. To access the } \\
\text { final edited and published work see https://doi.org/10.1021/acs.jafc.6b03339. }\end{array}$ \\
\hline DOI & 10.1021/acs.jafc.6b03339 \\
\hline
\end{tabular}

Self-Archiving by Author(s)

Placed on: Osaka City University

HONDA, S., \& MASUDA, T. (2016). Identification of Pyrogallol in the Ethyl Acetate-Soluble Part of Coffee as the Main Contributor to Its Xanthine Oxidase Inhibitory Activity. Journal of Agricultural and Food Chemistry. 64, 7743-7749. https://doi.org/10.1021/acs.jafc.6b03339 


\title{
Identification of Pyrogallol in the Ethyl-Acetate-Soluble Part of Coffee as the Main Contributor to Its Xanthine Oxidase Inhibitory Activity
}

\author{
Sari Honda and Toshiya Masuda*
}

Graduate School of Human Life Science, Osaka City University, Osaka 558-8585, Japan

Running Head: Pyrogallol, the main xanthine oxidase inhibitor in coffee

*Corresponding Author

(FAX: +81-6-6605-2813; E-mail: masuda_t@life.osaka-cu.ac.jp) 
ABSTRACT: In this study, ethyl-acetate-soluble parts of hot-water extracts from roasted coffee beans were found to demonstrate potent xanthine oxidase (XO) inhibition. The XO inhibitory activities and chlorogenic lactone contents (chlorogenic lactones have previously been identified as XO inhibitors in roasted coffee), were measured for ethyl-acetate-soluble parts prepared from coffee beans roasted to three different degrees. Although chlorogenic lactone contents decreased with higher degrees of roasting, the XO inhibitory activity did not decrease. These data caused us to investigate new potent inhibitors present in these ethyl-acetate-soluble extracts. Repeated assay-guided purifications afforded a highly potent XO inhibitor, which was eluted before chlorogenic lactones via medium-pressure chromatography using an octadecylsilica gel column. The obtained inhibitor was identified as pyrogallol (1,2,3-trihydroxybenzene), which had an $\mathrm{IC}_{50}$ of $0.73 \mu \mathrm{mol} \mathrm{L}{ }^{-1}$, much stronger than that of other related polyphenolic compounds. Quantitative analysis of pyrogallol and chlorogenic lactones revealed that pyrogallol (at the concentrations of $33.9 \pm 4.2 \mathrm{nmol} \mathrm{mL} \mathrm{m}^{-1}$ in lightly roasted coffee and $39.4 \pm 3.9 \mathrm{nmol} \mathrm{mL}^{-1}$ in darkly roasted coffee) was the main XO inhibitor in hot-water extracts of roasted coffee beans (i.e., drinking coffee).

KEYWORDS: pyrogallol, xanthine oxidase inhibitor, coffee, roasted beans, chlorogenic lactone 


\section{INTRODUCTION}

Coffee, made by brewing the roasted beans of tropical Coffea plants, is one of the most popular beverages globally. Coffee consumption has been increasing year on year, with $7.4 \times 10^{6}$ tons of coffee beans consumed worldwide in 2014 , according to the International Coffee Organization. ${ }^{1}$ This increase might be due to information regarding the positive effects of drinking coffee on human health, which is supported by new and significant scientific evidence. $^{2}$

In 2007, Choi et al. reported that a coffee drinking habit significantly reduces the incidence of gout. ${ }^{3}$ Gout, known as "the disease of kings" or "rich man's disease", is classical disease recognized now as being life-style-related. ${ }^{4,5}$ The number of patients with gout, and related hyperuricemia, is increasing significantly. In the USA, gout incidence approximately doubled between 1990 and 2010, ${ }^{6}$ while in Japan, the number of gout patients has increased three-fold in the last 20 years. ${ }^{5}$ Therefore, coffee could be a promising functional beverage to prevent gout. However, the compounds in coffee beverages that contribute to preventing gout have not yet been identified.

The expression of gout is known to result from the accumulation of excess serum uric acid, which is the final metabolite of purine catabolism in humans. ${ }^{7}$

Inhibiting xanthine oxidase (XO), a key enzyme catabolism, is one of the most effective 
methods for reducing the amount of serum uric acid. The relationship between coffee consumption and serum uric acid has been reported. ${ }^{8}$ Therefore, we sought to identify XO inhibitors in hot-water extracts of roasted coffee beans. Previously, we found that XO inhibitory activity was observed in roasted coffee bean extract, but not the extract of raw beans (unroasted green beans). Our subsequent investigation, using assay-guided purification, afforded several chlorogenic lactones that were XO inhibitors. ${ }^{9}$ The roasting process is necessary for the preparation of coffee beverages, with chlorogenic lactones reportedly produced from non-active chlorogenic acid during the roasting process. ${ }^{10}$ There are several degrees of roasting coffee, from light to dark, as well as more deeply roasted degrees, such as French and Italian. ${ }^{11}$ These degrees affect the amounts of chlorogenic acids (5-O-caffeoylquinic acid, 4- $O$-caffeoylquinic acid and 3-O-caffeoylquinic acid) and their lactone derivatives produced from chlorogenic acids via thermal dehydration during bean roasting. ${ }^{12}$ More recently, we found that the concentration of chlorogenic lactones did not fully correlate with the intensity of XO inhibitory activity in hot-water extracts from various roasted coffee beans. Therefore, we explored these extracts for other potent XO inhibitors. In this paper, we report the identification of a highly potent inhibitor and discuss its contribution to the $\mathrm{XO}$ inhibitory activity of coffee (the hot-water extract of roasted coffee beans.). 


\section{MATERIALS AND METHODS}

Chemicals and instruments. Chlorogenic acid (5-O-caffeoylquinic acid) was purchased from Funakoshi (Tokyo, Japan). Xanthine oxidase (XO) from butter milk, resorcinol, phloroglucinol, and perchloric acid were purchased from Wako Pure Chemicals (Osaka, Japan). 1,2,4-Trihydroxybenzene was purchased from Kanto Chemical (Tokyo, Japan). Catechol was obtained from Tokyo Kasei (Tokyo, Japan). Allopurinol and Sephadex LH-20 were obtained from Sigma-Aldrich (St. Louis, MO). All other reagents and solvents were purchased from Nacalai Tesque (Kyoto, Japan). The lightness of coffee bean powder was measured using a ZE 6000 Color Meter (Nippon Denshoku Industries, Tokyo, Japan) using $30 \mathrm{~mm}$ i.d. cell. NMR spectra were obtained from a JNM-ECZ400S (JEOL, Tokyo, Japan). MS spectra were measured using a JMS-T100 spectrometer (JEOL) with DART (Direct Analysis at Real Time) ionization and TOF (Time of Flight) measuring mode under the following conditions: orifice $1,10 \mathrm{~V}$; orifice $2,5 \mathrm{~V}$; ring lens, $10 \mathrm{~V}$; helium gas pressure, $0.5 \mathrm{MPa}$, flow rate of $10 \mathrm{~L} \mathrm{~min}^{-1}$; ion resource temperature, $350{ }^{\circ} \mathrm{C}$; grid voltage positive, $400 \mathrm{~V}$ for positive mode and $350 \mathrm{~V}$ for negative mode. Elemental compositions of compounds were calculated using MassLynx software, version 4.1 (Waters). Analytical HPLC was performed using a PU-2089 Plus quaternary gradient pump (JASCO, Tokyo, Japan) 
equipped with an MD-2018 photodiode array detector (JASCO), a CTO-10ASVP column oven (Shimadzu, Kyoto, Japan), and an AS-2055Plus intelligent sampler (JASCO). Data were analyzed using the ChromNAV software (v.2, JASCO).

Preparative HPLC was performed using an LC-6AD pump (Shimadzu) equipped with an SPD-6A UV detector (Shimadzu).

Coffee samples. Coffee beans in different roasted degrees [darkly roasted, moderately roasted, lightly roasted, and green (lightness value: $L^{*} 18.8,25.0,28.0$, and 61.6, respectively)] from the same origin (Coffea arabica species cultivated in Brazil) were provided by Ajinomoto General Foods, Inc. (Tokyo, Japan). Roasted coffee bean powder of Brazil Santos No.2 grade, which was used for inhibitor isolation, was purchased from a local coffee trading company (Jet-Coffee Co. Ltd, Sakai, Japan).

Assay for xanthine oxidase inhibition. Xanthine oxidase inhibition assay was carried out according to a previously reported method with slight modification. ${ }^{13}$ The reaction medium consisting of $10 \mu \mathrm{L}$ of $1 \mathrm{mmol} \mathrm{L}^{-1}$ xanthine in DMSO, $10 \mu \mathrm{L}$ of the test sample in DMSO, and $160 \mu \mathrm{L}$ of $12.5 \mathrm{mmol} \mathrm{L}^{-1}$ phosphate buffer (pH 7.8) was pre-incubated at $37^{\circ} \mathrm{C}$ for $5 \mathrm{~min}$. To this solution, $20 \mu \mathrm{L}$ of 0.027 unit $\mathrm{mL}^{-1} \mathrm{XO}$ solution ( $\mathrm{pH} 7.8$ phosphate buffer) was added. In the no pre-incubation method, test sample in DMSO was added to the xanthine buffer solution at the same time of addition of the 
enzyme solution. After incubation at $37^{\circ} \mathrm{C}$ for $10 \mathrm{~min}, 3 \% \mathrm{HClO}_{4}$ aq $(25 \mu \mathrm{L})$ was added to quench the reaction. An aliquot $(20 \mu \mathrm{L})$ of the solution was injected into the HPLC column to quantify the uric acid produced under the following conditions: column, a $250 \mathrm{~mm} \times 4.6 \mathrm{~mm}$ i.d., $5 \mu \mathrm{m}$, Mightysil RP-18 GP Aqua (Kanto Chemical); flow rate, $1.0 \mathrm{~mL} \mathrm{~min}^{-1}$; solvent, methanol-0.1\% phosphoric acid in water $(2.5: 97.5, \mathrm{v} / \mathrm{v})$; detection, $290 \mathrm{~nm}$; temperature, $35^{\circ} \mathrm{C}$. Percent Inhibition was calculated according to the following equation: inhibition $(\%)=[$ (peak area of uric acid in control experiment $)$ $-($ peak area of uric acid in sample experiment) $] \times 100 /$ (peak area of uric acid in control experiment).

\section{Preparation of the ethyl-acetate-soluble parts of hot-water extracts from}

\section{roasted and non-roasted green coffee beans and HPLC analysis of their}

constituents. Coffee bean power ( $2 \mathrm{~g})$, which was prepared from roasted or unroasted coffee beans (green beans) by milling using MJ516 coffee mill (Mellita Japan, Tokyo, Japan for roasted beans) or blender WB-1 (Osaka Chemical, Osaka, Japan, for green beans), was soaked in boiling water $(10 \mathrm{~mL})$ and then allowed to stand for $1 \mathrm{~h}$. After filtered with a filter paper (No.2, Advantec, Tokyo, Japan), the filtered solution was partitioned twice with ethyl acetate $(5 \mathrm{~mL})$. The combined ethyl acetate layers were evaporated to dryness to give an ethyl-acetate-soluble part of the extract of coffee beans. 
The water layer was also evaporated to give a water-soluble part. These obtained partitions were assayed for XO inhibitory activity.

\section{HPLC fractionation of the ethyl-acetate-soluble parts from darkly and}

rightly roasted coffee beans. Each ethyl acetate-soluble part (138 mg from darkly roasted beans and $144 \mathrm{mg}$ from lightly roasted beans, respectively), which was prepared by similar procedure described above, was separated into three fractions under the following HPLC conditions: column, a $250 \mathrm{~mm} \times 20 \mathrm{~mm}$ i.d., Cosmosil 5C18-AR-II (Nacalai Tesque); flow rate, $9.6 \mathrm{~mL} \mathrm{~min}^{-1}$; solvent $\mathrm{A}, 1 \%$ acetic acid in water, solvent $\mathrm{B}$, acetonitrile; gradient conditions, $15 \%$ of solvent B (0-25 min), $50 \%$ of solvent B (25.1$35 \mathrm{~min}$ ), and $100 \%$ of solvent B (35.1-55 min); detection, $320 \mathrm{~nm}$. The eluate before chlorogenic lactones (0-18 min), and the eluate containing chlorogenic lactones (18-25 $\mathrm{min})$, and the eluate after chlorogenic lactones (25-40 min) were collected and evaporated to afford fraction A (84 mg for darkly roasted beans and $94 \mathrm{mg}$ for lightly roasted beans), fraction B (10 $\mathrm{mg}$ for darkly roasted beans and $15 \mathrm{mg}$ lightly roasted beans), and fraction C (31 mg for darkly roasted beans and $34 \mathrm{mg}$ lightly roasted beans), respectively.

\section{Large-scale fractionation of the ethyl-acetate-soluble part of a hot-water}

extract from roasted coffee beans. To powder of roasted coffee beans ( $2 \mathrm{~kg}$; lightness 
value $\left.L^{*} 21.7\right)$ was added boiling water (10 L) and stirred occasionally for $2 \mathrm{~h}$. After filtration with a filter paper, the obtained solution was extracted twice with ethyl acetate (10 L). The ethyl acetate solution was evaporated to give an ethyl-acetate-soluble extract (32.3 g). A part of the extract (0.35 g) was subjected to medium pressure chromatography (MPLC) to separate into 10 fractions (yields after evaporation in order to elution: Fr. 1, 31.8 mg; Fr. 2, 15.5 mg; Fr. 3, 10.7 mg; Fr. 4, 105.4 mg; Fr. 5, 29.9 mg; Fr. 6, 9.8 mg; Fr. 7, 9.4 mg; Fr. 8, 5.7 mg; Fr. 9, 8.3 mg; Fr. 10, $12.1 \mathrm{mg}$, respectively) under the following conditions: column, a $300 \mathrm{~mm} \times 50 \mathrm{~mm}$ i.d., ULTRA PACK ODS-S-50 (Yamazen, Osaka, Japan); flow rate, $9.6 \mathrm{~mL} \mathrm{~min}^{-1}$; solvent, acetonitrile- $0.1 \%$ acetic acid in water $(12.5: 87.5, \mathrm{v} / \mathrm{v})$; detection, $320 \mathrm{~nm}$; fractionated volume, $310 \mathrm{~mL}$. The most active fraction 2 was separated again by preparative HPLC into six fractions (Fr. 2-1 2-6) under the following conditions: column, a $250 \mathrm{~mm} \times 20 \mathrm{~mm}$ i.d., Cosmosil 5C18-AR-II (Nacalai Tesque); flow rate, $9.6 \mathrm{~mL} \mathrm{~min}^{-1}$; solvent $\mathrm{A}, 0.1 \%$ acetic acid in water, solvent B, acetonitrile; gradient conditions, linear gradient of $5 \%$ of solvent B (0 $-16 \mathrm{~min}), 10 \%$ of solvent $\mathrm{B}(16.1-28 \mathrm{~min})$, and then $100 \%$ of solvent $\mathrm{B}(28.1-44 \mathrm{~min})$; and detection, $280 \mathrm{~nm}$. After evaporation of the fractions, their XO inhibitory activities were measured.

Isolation and identification of a potent XO inhibitor from fraction 2. The 
above-mentioned fraction $2(200 \mathrm{mg})$ was prepared again and purified by a similar procedure using MPLC and subsequent HPLC. A peak at retention time $6.5 \min (14.3$ $\mathrm{mg}$ ), which was corresponding to a major peak of the most active fraction 2-1, was separated. The peak substance was next purified by Sephadex LH-20 column chromatography (column size: column, a $560 \mathrm{~mm} \times 2.5 \mathrm{~mm}$ i.d.; solvent, methanol) to give a pure compound $\mathbf{1}(4 \mathrm{mg})$ as a potent $\mathrm{XO}$ inhibitor. $\mathbf{1}$ was then determined to be pyrogallol from the following NMR and MS data. ${ }^{1} \mathrm{H}$ NMR $\left(\mathrm{CD}_{3} \mathrm{OD}, 300 \mathrm{MHz}\right) \delta \mathrm{ppm}$ $6.31\left(2 \mathrm{H}, \underline{\mathrm{AA}^{\prime} \mathrm{B}}\right)$ and $6.51\left(1 \mathrm{H}, \mathrm{AA}^{\prime} \underline{\mathrm{B}}\right){ }^{14}{ }^{14} \mathrm{DART}-\mathrm{TOFMS} \mathrm{m} / \mathrm{z} 127.0383[\mathrm{M}+\mathrm{H}]^{+}$, calcd for $\mathrm{C}_{6} \mathrm{H}_{5} \mathrm{O}_{3}: 127.0395$ and $\mathrm{m} / \mathrm{z} 125.0231[\mathrm{M}-\mathrm{H}]^{-}$, calcd for $\mathrm{C}_{6} \mathrm{H}_{3} \mathrm{O}_{3}, 125.0239$.

\section{Quantitative analysis of pyrogallol (1), chlorogenic acids (2-4) and}

chlorogenic lactones (5 and 6 ) in coffee bean extracts. Amounts of pyrogallol (1), chlorogenic acids (2-4) and chlorogenic lactones (5 and 6) in the ethyl-acetate-soluble parts and the water-soluble parts from hot-water extracts of roasted and unroasted coffee beans were quantitatively analyzed by HPLC technique. Each extract sample $(5.0 \mathrm{mg})$ was dissolved in DMSO $(278 \mu \mathrm{L}$ or $556 \mu \mathrm{L})$ and then $10 \mu \mathrm{L}$ of the solution was injected into HPLC. The containing pyrogallol was analyzed under the following conditions, column, a $250 \mathrm{~mm} \times 4.6 \mathrm{~mm}$ i.d., $5 \mu \mathrm{m}$, J-Pak Symphonia C18 (JASCO); flow rate, 1.0 $\mathrm{mL} \min ^{-1}$; solvent $\mathrm{A}, 0.1 \%$ phosphoric acid in water; solvent $\mathrm{B}$, acetonitrile; gradient 
conditions, linear gradient from 0 to $10 \%$ solvent B (10 to $20 \mathrm{~min}$ ), and then to $100 \%$ solvent B (25 to $40 \mathrm{~min}$ ); and detection, $268 \mathrm{~nm}$. The amounts of chlorogenic acids (24) and chlorogenic lactones (5 and $\mathbf{6}$ ) were analyzed under the conditions: column, a $250 \mathrm{~mm} \times 4.6 \mathrm{~mm}$ i.d., $5 \mu \mathrm{m}$, Cosmosil 5C18-AR-II (Nacalai Tesqure); flow rate, 1.0 $\mathrm{mL} \min ^{-1}$; solvent $\mathrm{A}, 1 \%$ acetic acid in water, solvent $\mathrm{B}$, acetonitrile; gradient conditions, linear gradient from 5 to $45 \%$ solvent B (0-40 $\mathrm{min}$ ) and then to $100 \%$ solvent B (50-55 min); and detection, $320 \mathrm{~nm}$. From the obtained peak areas, containing amount of each compound was calculated using a corresponding calibration curve for pyrogallol: $\mathrm{y}=$ $27,700 \mathrm{x}-5,879$ (range of $\mathrm{x}: 2.5-25 \mathrm{nmol}$ ), and for chlorogenic acids and lactones: $\mathrm{y}=$ $905,995 \mathrm{x}+135,060$ (range of $\mathrm{x}: 0.5-5 \mathrm{nmol}$ ); where y is peak area at $268 \mathrm{~nm}$ for pyrogallol and at $320 \mathrm{~nm}$ for chlorogenic acids and lactones, and $\mathrm{x}$ is amount (nmol) of each pure compound.

Statistical Analysis. The data for discussion on quantitative difference are expressed as the means \pm standard deviation of the mean (SD). Significant differences between two experimental groups were determined by Student's $t$-test (Statistic analysis add-in software 2015 for Microsoft Excel 2013, SSRI, Tokyo, Japan) with $p<0.05$ indicating significance. 


\section{RESULTS AND DISCUSSION}

\section{XO inhibitory activity of extracts from darkly roasted, moderately roasted,}

\section{lightly roasted, and unroasted green coffee beans, and their chlorogenic lactone}

contents. Previously, we found significant xanthine oxidase (XO) inhibitory activity in roasted coffee bean extracts, but none in unroasted green coffee bean extracts.

Assay-guided purification, using size exclusion chromatography, allowed us to identify several chlorogenic lactones as XO inhibitors characteristic of roasted coffee beans

(Figure 1). ${ }^{9}$ Chlorogenic lactones are known to be generated from chlorogenic acids in green coffee beans during the roasting process, with amounts of these lactones varying according to the degree of roasting. ${ }^{10,12}$ Therefore, we assumed that the lactone contents in coffee bean extracts affected the XO inhibitory activity of coffee beverages. For this investigation, we obtained roasted beans with three different degrees of roasting: darkly roasted beans $\left(\mathrm{L}^{*} 18.8\right)$, moderately roasted beans $\left(\mathrm{L}^{*} 25.0\right)$, and lightly roasted beans ( $\left.\mathrm{L}^{*} 28.0\right)$, as well as unroasted green beans $\left(\mathrm{L}^{*} 61.6\right)$ of the same origin. Hot-water extracts were prepared from these four bean types using boiling water, as if brewing coffee. The XO inhibition of these extracts was measured; however, the inhibition values obtained were too low for a comparison. Therefore, we developed a new pretreatment method to obtain higher XO inhibition values. Each hot-water extract was 
partitioned twice with an equal volume of ethyl acetate in a separatory funnel with vigorous shaking. The chlorogenic lactones mostly transferred to the ethyl acetate layer, which showed significantly higher XO inhibitory activities (>60\% at $0.3 \mathrm{mg} \mathrm{mL}^{-1}$ ). These values were sufficient to evaluate activities precisely, whereas the residual water layer showed almost no activity. Table 1 shows the yields, amounts of lactones, and XO inhibitory activities of the ethyl-acetate-soluble parts prepared from three types of roasted beans and unroasted beans. Although chlorogenic lactones were notably present in lightly roasted beans, their contents decreased with darker roasting, in agreement with results of an earlier study. ${ }^{10}$ However, the XO inhibitory activities showed little variation, regardless of the degree of roasting. These results strongly indicated that another active compound, which was likely produced by roasting coffee beans and might be more stable under thermal treatment, existed in the ethyl acetate parts of the hot-water extracts from roasted beans. Next, we prepared three fractions by high performance liquid chromatography (HPLC) using an octadecylsilica gel (ODS) column: fraction A, eluted before chlorogenic lactones; fraction B, containing chlorogenic lactones; and fraction $\mathrm{C}$, eluted after chlorogenic lactones (Figure 2). The yields, lactone contents, and $\mathrm{XO}$ inhibitory activities $\left(\mathrm{IC}_{50}\right)$ of these fractions derived from lightly and darkly roasted beans are summarized in Table 2. Although fraction B 
(chlorogenic lactone fraction) gave the most potent XO inhibitory activity, it was not much greater than that of fraction A in samples from both roasted beans. The yield of fraction A was higher than those of fractions B and C. These results strongly indicated that fraction A contributed most to XO inhibitory activity, regardless of the degree of roasting.

\section{Identification of pyrogallol as an XO inhibitor by assay-guided}

purification of fraction A. Large-scale preparation was carried out using commercially available roasted coffee powder $(2 \mathrm{~kg})$, which afforded $32 \mathrm{~g}$ of the ethyl-acetate-soluble part of the hot-water extract. This ethyl-acetate-soluble part was subjected to medium pressure liquid chromatography (MPLC), which afforded 10 newly obtained fractions in the eluate before chlorogenic lactones were eluted. The XO inhibition assay results for these 10 fractions (Fr. No. 1-10) are shown in Figure 3. Fraction 2 showed very strong activity (almost 100\% inhibition) at a concentration of $0.15 \mathrm{mg} \mathrm{mL}^{-1}$, and contained a number of compounds, as indicated by numerous peaks observed in its HPLC profile, as shown in Figure 4. Therefore, further fractionation was carried out to separate fraction 2 into 6 new fractions (Fr. No. 2-1 to 2-6) and their XO inhibitory activities were examined, as shown in Figure 5. Fraction 2-1 had the most potent activity among these fractions. Final purification of fraction 2-1 was achieved using Sephadex LH-20 column 
chromatography, giving pure compound 1. Structure elucidation was performed for $\mathbf{1}$ using NMR and MS analyses. High-resolution DART (direct analysis in real time) MS of 1 gave molecular-related ions at $m / z$ 127.0383 [M+H] ${ }^{+}$and $125.0231[\mathrm{M}-\mathrm{H}]^{-}$, indicating that its molecular formula was $\mathrm{C}_{6} \mathrm{H}_{6} \mathrm{O}_{3}$. In the ${ }^{1} \mathrm{H}$ NMR data of $\mathbf{1}$, two sets of protons were observed at $6.31 \mathrm{ppm}(2 \mathrm{H})$ and $6.51 \mathrm{ppm}(1 \mathrm{H})$, coupled to each other in an AA'B pattern. These data confirmed that 1 was pyrogallol (1,2,3-trihydroxybenzene). The XO inhibitory activity of pyrogallol was measured under our conditions, the $\mathrm{IC}_{50}$ value was determined to be $0.73 \mu \mathrm{mol} \mathrm{L} \mathrm{L}^{-1}$. This confirmed that the activity of pyrogallol was very strong, with a value comparable to that of allopurinol $\left(\mathrm{IC}_{50}=0.5 \mu \mathrm{mol} \mathrm{L}{ }^{-1}\right)$, a potent XO-inhibitory medicine for gout. The XO inhibitory activity of pyrogallol was previously reported by Gray and Felher, ${ }^{15}$ but their results showed it to have weak activity $\left(68 \%\right.$ and $44 \%$ inhibition at concentrations of 0.01 and $0.001 \mathrm{~mol} \mathrm{~L}^{-1}$, respectively) using an $\mathrm{O}_{2}$ consumption method. Pyrogallol was identified as a minor constituent, along with aroma compounds, in coffee, ${ }^{16}$ and its mechanism of formation from chlorogenic acid during coffee processing has been proposed by Müller et al. ${ }^{17}$ However, Haffenden and Yaylayan ${ }^{18}$ also reported that pyrogallol can be derived from glucose by thermal treatment. In any case, pyrogallol is a minor constituent, but, strong XO inhibitor, produced in high-temperature chemical reactions, such as coffee roasting. 


\section{XO inhibitory activities of pyrogallol and related phenols. Roasted coffee}

contains various phenols, which are produced during roasting. ${ }^{16}$ We measured the percentage XO inhibitory activities of six tri- and di-hydroxybenzenes including pyrogallol, at $200 \mu \mathrm{mol} \mathrm{L}{ }^{-1}$, as summarized in Table 3. Among these phenols, pyrogallol had the highest activity ( $>100 \%)$, followed by other trihydroxy compounds.

1,2,4-Trihydroxybenzene showed significant activity, although it was much lower than that of pyrogallol. Other phenols did not have significant activity at the concentrations used. Therefore, the 1,2,3-trihydroxybenzene structure is important for XO inhibition. The XO inhibitory activities of various gallic esters and gallocatechins, bearing the same 1,2,3-trihydroxybenzene moiety as pyrogallol, have also been reported. ${ }^{19,20}$

\section{Contribution of pyrogallol to XO inhibitory activity of roasted coffee bean}

extracts. Having identified the active XO inhibitory compounds, namely pyrogallol and chlorogenic lactones, in the hot-water extracts of roasted coffee beans in current and previous studies, ${ }^{9}$ the question arose of which compound contributed most to the $\mathrm{XO}$ inhibitory activity of coffee. Therefore, we estimated the contributions of these compounds to the XO inhibitory activity of roasted coffee bean hot-water extracts using quantitative analysis of the active compounds. Figure 6 shows the HPLC analytical data for pyrogallol (panel A) and chlorogenic lactones (panel B) in the ethyl-acetate-soluble 
part of the hot-water extract of roasted coffee beans. Using conditions described in the experimental section, we succeeded in quantifying the pyrogallol content from the completely separated peak at a retention time $15.8 \mathrm{~min}$ (Figure 6, panel A), as well as two chlorogenic lactones [3-O-caffeoyl-1,5-quinide (5) and 4-O-caffeoyl-1,5-quinide (6)] and three chlorogenic acids [5-O-caffeoylquinic acid (2), 4-O-caffeoylquinic acid (3), and 3-O-caffeoylquinic acid (4)] under other conditions (Figure 6, panel B). Table 4 summarizes the analytical data obtained for extracts of lightly roasted, darkly roasted, and unroasted green beans. Most chlorogenic acids were found in the water-soluble part of the hot-water extracts, while most chlorogenic lactones and pyrogallol were present in the ethyl-acetate-soluble-part. Pyrogallol contents in the ethyl acetate part were very small $\left(<0.04 \mu \mathrm{mol} \mathrm{mL} \mathrm{m}^{-1}\right.$ of hot-water extract $)$, but not significantly different between the lightly and darkly roasted bean extracts. Chlorogenic lactone contents were higher than those of pyrogallol (sum of lactones 5 and $\mathbf{6}=0.1-0.2 \mu \mathrm{mol} \mathrm{mL} \mathrm{m}^{-1}$ of hot-water extract) and varied depending on the degree of roasting, with half the amount extracted from darkly roasted beans compared with that from lightly roasted beans. Although chlorogenic acid was found to have almost no XO inhibitory activity, its lactone derivatives showed meaningful activity. ${ }^{9}$ In the current investigation, we found a minor compound, pyrogallol, to be the more potent $\mathrm{XO}$ inhibitor. Its activity was estimated to 
be $\sim 400$ times greater than that of chlorogenic lactones, based on their $\mathrm{IC}_{50}$ values $\left(0.73 \mu \mathrm{mol} \mathrm{L}{ }^{-1}\right.$ for pyrogallol; $285 \mu \mathrm{mol} \mathrm{L}^{-1}$ as a mean value for chlorogenic lactones 5 and 6). Considering both activity and quantity in coffee extracts, as shown in Table 4, pyrogallol should make the biggest contribution to XO inhibition in hot-water extracts of roasted coffee beans, regardless of the degree of roasting. Interestingly, the percentage contribution of pyrogallol, to the activity of the ethyl acetate extracts was much more than $100 \%$ (197\% for lightly roasted bean extract and $207 \%$ for darkly roasted bean extract), calculated using the following equation: contribution $(\%)=$ [(mass concentration of pyrogallol in the corresponding concentration of the ethyl acetate extract just showing $\left.\mathrm{IC}_{50}\right) /\left(\mathrm{IC}_{50}\right.$ value of pyrogallol)]. It should be noted that raw food extracts sometimes promote XO activity. ${ }^{21}$ In the case of coffee, we also observed high-weight molecules in hot-water extracts of roasted coffee beans, obtained by size exclusion chromatography, that showed significant promotion of XO activity. ${ }^{9}$ In the HPLC profile (Figure 6A), pyrogallol is a very minor component, and various other compounds were observed in the HPLC data of extracts. Therefore, compounds with reductive effects on the net activity of pyrogallol could exist in the extracts.

Although pyrogallol was found to be the main contributor to XO inhibitory activity in coffee (hot-water extracts of roasted coffee beans) in this investigation, its 
inhibition mechanism is still unclear. Pyrogallol is known to be not very stable under alkaline conditions, including the present buffer system ( $\mathrm{pH} 7.8$ ), and consumes molecular oxygen during degradation. We carried out an XO inhibitory assay under the modified conditions without pre-incubation of pyrogallol in the same buffer, which gave a slightly raised $\mathrm{IC}_{50}$ value, $1.19 \mu \mathrm{mol} \mathrm{L}{ }^{-1}$ from $0.73 \mu \mathrm{mol} \mathrm{L}^{-1}$ of the original method, indicating that more potent inhibitors might be produced during the pre-incubation time of the previous assay. Although HPLC analysis of pyrogallol content in the assay buffer $(\mathrm{pH} 7.8)$ revealed that it decreased gradually until ca. $70 \%$ in 5 min (pre-incubation time). However, this reduction did not occur immediately after the start of the enzymatic reaction using the no pre-incubation method. These results indicated that pyrogallol was not very stable under the assay conditions, while pyrogallol showed XO inhibitory activity and some products of pyrogallol enhanced activity.

Recently, some polyphenols, especially catechol compounds such as pyrogallol, are candidates for promiscuous inhibitors of various enzymes as pan assay interference compounds (PAINS) in high-throughput screening. ${ }^{22,23}$ Although hydrophobicity is one property of PAINS, pyrogallol is not very hydrophobic. Furthermore, the XO inhibitory activity of pyrogallol in the presence of $0.01 \%$ Triton-X100 was not different from that in absence of the detergent. ${ }^{24}$ In addition, similar catechol-bearing 
hydroxyhydroquinone (1,2,4-trihydroxybenzene) showed only weak XO inhibition.

(Table 3). Although these results showed pyrogallol might not be a promiscuous inhibitor, the inhibitory mechanism of pyrogallol is still somewhat unclear because of instability of pyrogallol. Further intensive investigation of the XO inhibitory activity of pyrogallol is necessary.

\section{Acknowledgements.}

We thank Dr. Shigeyoshi Fujii of Ajinomoto General Foods Inc. (AGF) for the helpful discussion and for providing various coffee beans of the same origins. We also thank Dr. Akiko Masuda of Shikoku University for coffee bean color measurements. S. H. thanks JSPS for a DC research fellowship.

Financial support: JSPS Kakenhi (Grant No. JP15H02892 for T. M. and JP16J03454 for S. H.) and a collaborative research fund between AGF and Osaka City University.

\section{REFERENCES}

(1) International Coffee Organization, Historical data [cited 2016, June 1]. Available from:

http://www.ico.org/historical/1990\%20onwards/PDF/1a-total-production.pdf. 
(2) Ludwig, I. A.; Clifford, M. N.; Lean, M. E.; Ashihara, H.; Crozier, A. Coffee: biochemistry and potential impact on health. Food Function 2014, 5, 16951717.

(3) Choi H. K.; Willett W.; Curhan G. Coffee consumption and risk of incident gout in men. Arthritis Rheum. 2007, 56, 2049-2055.

(4) Doherty, M. New insights into the epidemiology of gout, Rheumatology 2009, 48, ii2-ii8.

(5) Japan Society of Gout and Nucleic Acid Metabolism, Guideline for the management of hyperuricemia and gout 2nd digest ed., Medical Review: Osaka, pp 4-6, 2009.

(6) Weaver A. L. Epidemiology of gout, Cleve. Clin. J. Med. 2008, 75, Suppl. 5: S9-S12.

(7) Neogi, T. Gout. New Eng. J. Med. 2011, 364, 443-452.

(8) Pham, N. M.; Yoshida, D.; Morita, M.; Yin, G.; Toyomura, K.; Ohnaka, K.; Takayanagi, R.; Kono, S. The relation of coffee consumption to serum uric acid in Japanese men and women aged 49-76 years. J. Nutri. Metabol. 2010, 1-7.

(9) Honda, S.; Miura, Y. Masuda, A.; Masuda, T. Identification of crypto- and neochlorogenic lactones as potent xanthine oxidase inhibitors in roasted coffee 
beans. Biosci. Biotechnol. Biochem. 2014, 78, 2110-2116.

(10) Farah, A.; Paulis, T. D, Trugo, L. C.; Martin, P. R. Effect of roasting on the formation of chlorogenic acid lactones in coffee. J. Agric. Food Chem. 2005, 53, $1505-1513$.

(11) Hunter Associates Laboratory. Color measurement of roasted coffee using HunterLab spectrophotometer. Coffee White Paper-final 1_14.pdf [cited 2016, June 1] Available from: http://www.hunterlab.com/

(12) Bennat, C.; Engelhardt, U. H.; Kiehne, A.; Wirries, F.-M.; Maier, H. G. HPLC analysis of chlorogenic acid lactones in roasted coffee. Z. Lebenzm Unters Forsch. 1994, 199, 17-21

(13) Masuda, T.; Shingai, Y.; Takahashi, C.; Inai, M.; Miura, Y.; Honda, S; Masuda, A. Identification of a potent xanthine oxidase inhibitor from oxidation of caffeic acid, Free Radic. Biol. Med. 2014, 69, 300-307.

(14) SDBSWeb : http://sdbs.db.aist.go.jp (National Institute of Advanced Industrial Science and Technology (Accessed Jul. 10, 2016)

(15) Gray, S. J.; Felsher, R. Z. Studies on the inhibition of xanthine oxidase, Exp. Biol. Med. 1945, 59, 287-289.

(16) Clifford, M. N. Chemical and physical aspects of green coffee and coffee. In 
Coffee Botany, Biochemistry and Production of Beans and Beverage, American

edition; Eds Clifford, M. N.; Willson, K. C.; AVI: Westport, 1985; pp 305-374.

(17) Müller, C.; Lang, R.; Hofmann, T. Quantitative precursor studies on di- and trihydroxybenzene formation during coffee roasting using "in bean" model experiments and stable isotope dilution analysis. J. Agric. Food Chem. 2006, 54, 10086-10091.

(18) Hafenden L. J. W.; Yaylayan, V. A, Mechanism of formation of redox-active hydroxylated benzenes and pyrazine in ${ }^{13} \mathrm{C}$-labeled glycine/D-glucose model systems. J. Agric. Food Chem. 2005, 53, 9742-9746.

(19) Masuoka, N.; Nihei, K.-I.; Kubo, I. Xanthine oxidase inhibitory activity of alkyl gallates. Mol. Nutri. Food Res. 2006, 50, 725-731.

(20) Lin, J.-K.; Chen, P.-C.; Ho, C.-T.; Lin-Shiau, S.-Y. Inhibition of xanthine oxidase and suppression of intracellular reactive oxygen species in HL-60 Cells by theaflavin-3,3'-digallate, (-)-epigallocatechin-3-gallate, and propyl gallate. $J$. Agric. Food Chem. 2000, 48, 2736-2743.

(21) Dew, T. P.; Day, A. J.; Morgan, R. A. Xanthine oxidase activity in vitro: effects of food extracts and components. J. Agric. Food Chem. 2005, 53, 6510-6515.

(22) Feng, B. Y.; Shelat, A.; Doman, T. N.; Guy, R. K.; Shoichet, B. K.; 
High-throughput assays for promiscuous inhibitors, Nat. Chem. Biol. 2005, 1, $146-148$.

(23) Baell, J. B. Feeling nature's PAINS: Natural products, natural product drugs, and pan assay interference compounds (PAINS). J. Nat. Prod. 2016, 79, 616628.

(24) McGovernn S. L.; Helfand B. T.; Feng, B.; Shoichet, B. K.. A specific mechanism of nonspecific inhibition. J. Med. Chem., 2003, 246, 4265-4272. 


\section{Figure Captions}

Figure 1. Chemical structures of pyrogallol (1), chlorogenic acids (2-4), chlorogenic lactones (5 and 6), and pyrogallol-related phenols (7-11).

Figure 2. HPLC fractionation pattern for the ethyl-acetate-soluble part of a lightly roasted bean hot-water extract.

Figure 3. XO inhibitory activities of the fractions $\left(0.15 \mathrm{mg} \mathrm{mL}^{-1}\right)$ obtained by MPLC from the ethyl-acetate-soluble part of a roasted coffee bean hot-water extract.

Data are expressed as the mean $\pm \mathrm{SD}(n=3) .{ }^{*}$ Significant against control $(t$-test, $p<$ $0.05)$.

Figure 4. HPLC profile for fraction 2, the most active fraction of the ethyl-acetate-soluble part of a roasted coffee bean hot-water extract, and fractionated positions for fractions 2-1 2-6. 
Figure 5. XO inhibitory activity of fractions 2-1 2-6.

Data are expressed as the mean $\pm \mathrm{SD}(n=3) .{ }^{*}$ Significant against control $(t$-test, $p<$ $0.05)$.

Figure 6. HPLC analytical results for pyrogallol (1) A, chlorogenic acids (2-4), and chlorogenic lactones (5 and 6 ) of the ethyl-acetate-soluble part of a coffee Bean hot-water extract.

HPLC Profile A (Upper Data), analytical conditions: column, J-Pak Symphonia C18 $(250 \times 4.6 \mathrm{~mm}$ i.d. $)$; solvent A: $0.1 \%$ phosphoric acid in water, solvent $\mathrm{B}: \mathrm{CH}_{3} \mathrm{CN}$; gradient conditions [percent of solvent B (time)], 0\% (10 min), 10\% (20 min), 100\% (25$40 \mathrm{~min}$ ); flow rate, $1.0 \mathrm{~mL} \mathrm{~min}^{-1}$; detection, $268 \mathrm{~nm}$.

HPLC Profile B (Lower Data), analytical conditions: column, Cosmosil 5C18-AR-II $(250 \times 4.6 \mathrm{~mm}$ i.d. $)$; solvent $\mathrm{A}: 1 \%$ acetic acid in water, solvent $\mathrm{B}: \mathrm{CH}_{3} \mathrm{CN}$; gradient conditions [percent of solvent B (time)], 5\% (0 min), 45\% (40 min), 100\% (50-55 min); flow rate, $1.0 \mathrm{~mL} \mathrm{~min}^{-1}$; detection, $320 \mathrm{~nm}$. 
Table 1. Chlorogenic Lactone Contents and Xanthine Oxidase Inhibitory Activities of Ethyl-Acetate-Soluble Parts of Hot-Water Extracts from Green and Roasted Coffee Beans.

\begin{tabular}{|c|c|c|c|c|}
\hline & $\begin{array}{l}\text { unroasted } \\
\text { (green) } \\
\text { beans }\end{array}$ & $\begin{array}{l}\text { lightly } \\
\text { roasted } \\
\text { beans }\end{array}$ & $\begin{array}{l}\text { moderately } \\
\text { roasted beans }\end{array}$ & $\begin{array}{c}\text { darkly } \\
\text { roasted } \\
\text { beans }\end{array}$ \\
\hline lightness (L*) & 61.6 & 28.0 & 25.0 & 18.8 \\
\hline $\begin{array}{l}\text { yield of ethyl acetate-soluble part } \\
\text { (mg/10 mL hot water extract) }\end{array}$ & 16.0 & 17.0 & 19.2 & 17.7 \\
\hline $\begin{array}{l}\text { chlorogenic lactone content } \\
\text { a } \\
\text { amol/mg of the ethyl } \\
\text { acetate-soluble part })\end{array}$ & $-b$ & 0.173 & 0.131 & 0.053 \\
\hline $\begin{array}{l}\text { \% inhibition } \\
\left(0.3 \mathrm{mg} \mathrm{mL}^{-1}\right)^{\mathrm{c}}\end{array}$ & $2.86 \pm 3.54$ & $60.2 \pm 0.4^{\mathrm{d}}$ & $59.4 \pm 2.3^{\mathrm{d}}$ & $64.6 \pm 3.2^{\mathrm{d}}$ \\
\hline
\end{tabular}

${ }^{\mathrm{a}}$ Sum of lactone 6 and 7 ; ${ }^{\mathrm{b}}$ Not detected. $(<0.0025 \mathrm{nmol}) ;{ }^{\mathrm{c}}$ Data are expressed as the mean $\pm \mathrm{SD}(n=3)$; ${ }^{\mathrm{d}}$ Significant against control data $(t$-test, $p<0.05)$. 
Table 2. XO Inhibitory Activities and Chlorogenic Lactone Content in Three Fractions from the Ethyl-Acetate-Soluble Parts of Roasted Coffee Bean Hot-Water Extracts.

\begin{tabular}{|c|c|c|c|c|}
\hline \multirow{5}{*}{$\begin{array}{c}\text { roasted bean } \\
\text { sample }\end{array}$} & & yield & chlorogenic & \multirow{5}{*}{$\mathrm{IC}_{50}\left(\mathrm{mg} \mathrm{mL}^{-1}\right)$} \\
\hline & & $(\mathrm{mg} / \mathrm{mL}$ & lactone content ${ }^{a}$ & \\
\hline & fraction name & of & $(\mu \mathrm{mol} / \mathrm{mL}$ of & \\
\hline & & hot-water & hot-water & \\
\hline & & extracts) & extracts) & \\
\hline lightly roasted & A & 1.87 & $-^{\mathrm{b}}$ & 0.161 \\
\hline \multirow[t]{2}{*}{ beans } & B & 0.30 & 0.339 & 0.075 \\
\hline & $\mathrm{C}$ & 0.67 & - & 0.284 \\
\hline darkly roasted & $\mathrm{A}$ & 1.69 & - & 0.070 \\
\hline \multirow[t]{2}{*}{ beans } & B & 0.19 & 0.165 & 0.066 \\
\hline & $\mathrm{C}$ & 0.63 & - & 0.169 \\
\hline
\end{tabular}

${ }^{\mathrm{a}}$ Sum of contents of lactone $\mathbf{6}$ and $7 ;{ }^{\mathrm{b}}$ Not detected. $(<0.0025 \mathrm{nmol})$ 
Table 3. XO Inhibitory Activities of Pyrogallol-Related Phenols.

\begin{tabular}{ccc} 
compound & \% inhibition at $200 \mu \mathrm{mol}$ & \\
& $\mathrm{L}^{-1}(\operatorname{mean} \pm \mathrm{SD}, n=3)$ & $\mathrm{IC}_{50}{ }^{\mathrm{a}}\left(\mu \mathrm{mol} \mathrm{L}^{-1}\right)$ \\
\hline pyrogallol (1) & $-^{\mathrm{b}}$ & 0.73 \\
1,2,4-trihydroxybe & $31.7 \pm 1.5^{\mathrm{c}}$ & $\mathrm{nd}^{\mathrm{d}}$ \\
nzene (7) & & \\
phloroglucinol (8) & $5.92 \pm 0.21$ & $\mathrm{nd}$ \\
hydroquinone (9) & $-8.94 \pm 1.0$ & $\mathrm{nd}$ \\
catechol (10) & $-3.39 \pm 2.4$ & nd \\
resorcinol (11) & $-0.41 \pm 2.6$ & nd \\
\hline
\end{tabular}

${ }^{\mathrm{a}} \mathrm{IC}_{50}$ of allopurinol, a positive control, was $0.50 \mu \mathrm{mol} \mathrm{L}{ }^{-1} \cdot{ }^{\mathrm{b}} 100 \%$ at the concentration

of $200 \mu \mathrm{mol} \mathrm{L}^{-1} \cdot{ }^{\mathrm{c}}$ Significant against control data $(t$-test, $p<0.05) .{ }^{\mathrm{d}}$ Not determined. 
Table 4. Contents for Chlorogenic Acids, Chlorogenic Lactones, and Pyrogallol in Ethyl Acetate- and Water-Soluble Parts of Hot-Water Extracts from Lightly, Darkly Roasted, and Unroasted Coffee Beans, and the XO Inhibitory Activity of Each Soluble Part.

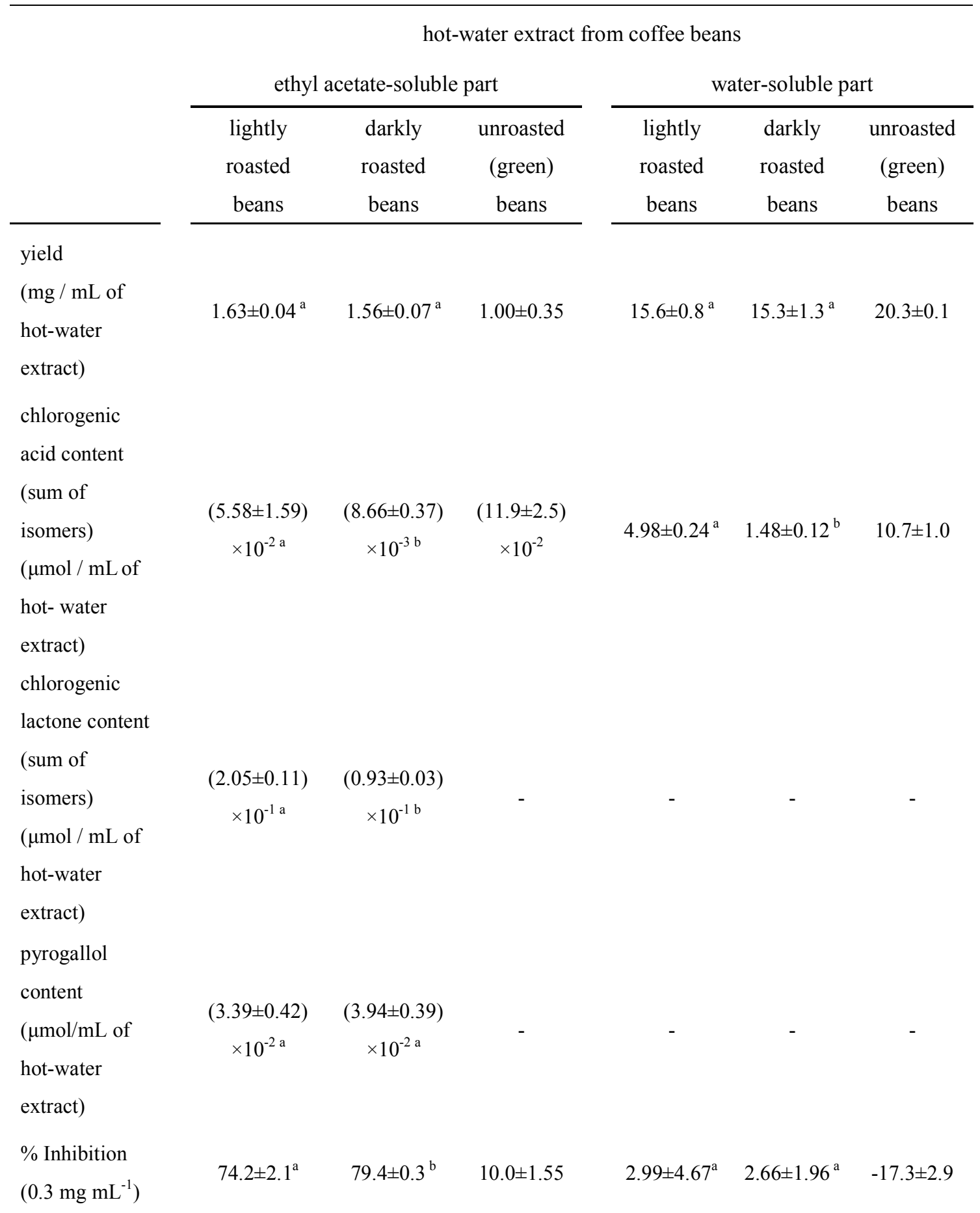


$\begin{array}{llllll}\mathrm{IC}_{50}\left(\mathrm{mg} \mathrm{mL}^{-1}\right) & 0.069 & 0.059 & \text { nd } & \text { nd } & \text { nd }\end{array}$

Data are expressed as the mean \pm SD $(n=3)$. -: Not detected $(<0.005 \mathrm{nmol})$. nd: Not determined. Mean values between the data from darkly and lightly roasted beans with the same superscript letter do not show significant difference $(p<0.05, t$-test). 
<smiles>Oc1cccc(O)c1O</smiles>

Pyrogallol (1)

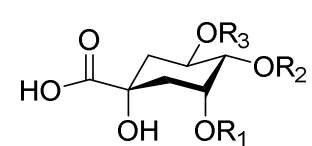

5-O-Caffeoylquinic acid (2) $\mathrm{R}_{1}: \mathrm{H}$

$\mathrm{R}_{2}: \mathrm{H}$

$\mathrm{R}_{3}$ :Caffeoyl

4-O-Caffeoylquinic acid (3) $\mathrm{R}_{1}: \mathrm{H}$

$\mathrm{R}_{2}:$ Caffeoyl

$\mathrm{R}_{3}: \mathrm{H}$

3-O-Caffeoylquinic acid (4) $\mathrm{R}_{1}$ :Caffeoyl

$\mathrm{R}_{2}: \mathrm{H}$

$\mathrm{R}_{3}: \mathrm{H}$

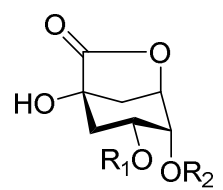

3-O-Caffeoyl-1,5-quinide (5) $\mathrm{R}_{1}$ :Caffeoyl

$\mathrm{R}_{2}: \mathrm{H}$

4-O-Caffeoyl-1,5-quinide (6) $\mathrm{R}_{1}: \mathrm{H}$

$\mathrm{R}_{2}:$ Caffeoyl<smiles>Oc1ccc(O)c(O)c1</smiles>

1,2,4-Trihydroxybenzene (7)<smiles>Oc1cc(O)cc(O)c1</smiles>

Phloroglucinol (8)<smiles>Oc1ccc(O)cc1</smiles>

Hydroquinone (9)<smiles>Oc1ccccc1O</smiles>

$\mathrm{HO}$<smiles>Oc1cccc(I)c1</smiles>

Catechol (10) Resorcinol (11)

Figure 1 


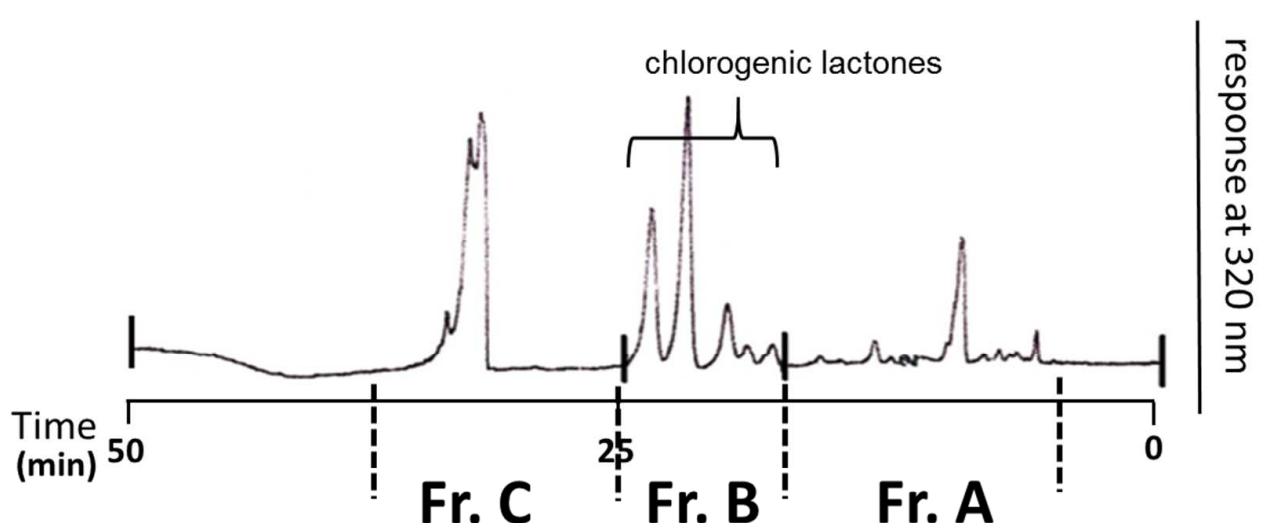

Figure 2 


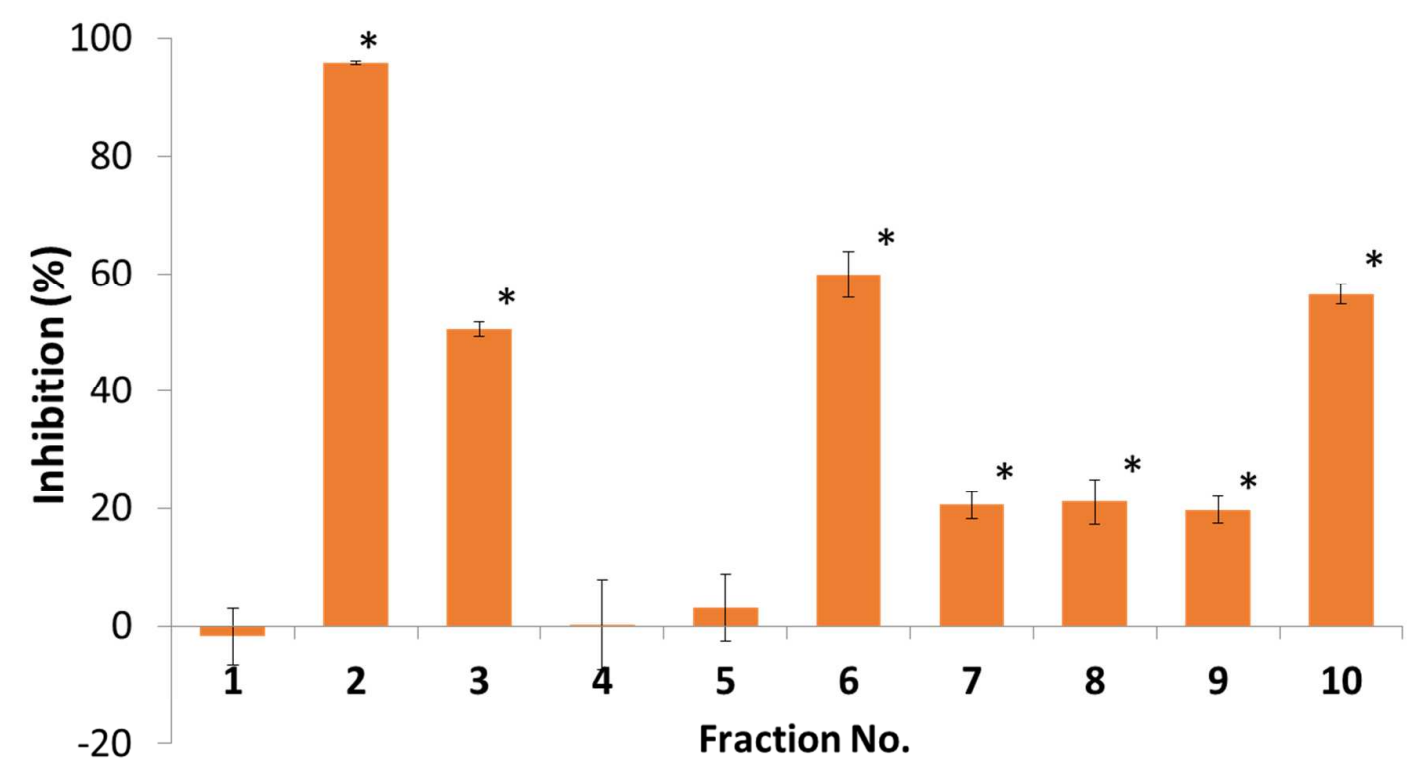

Figure 3 


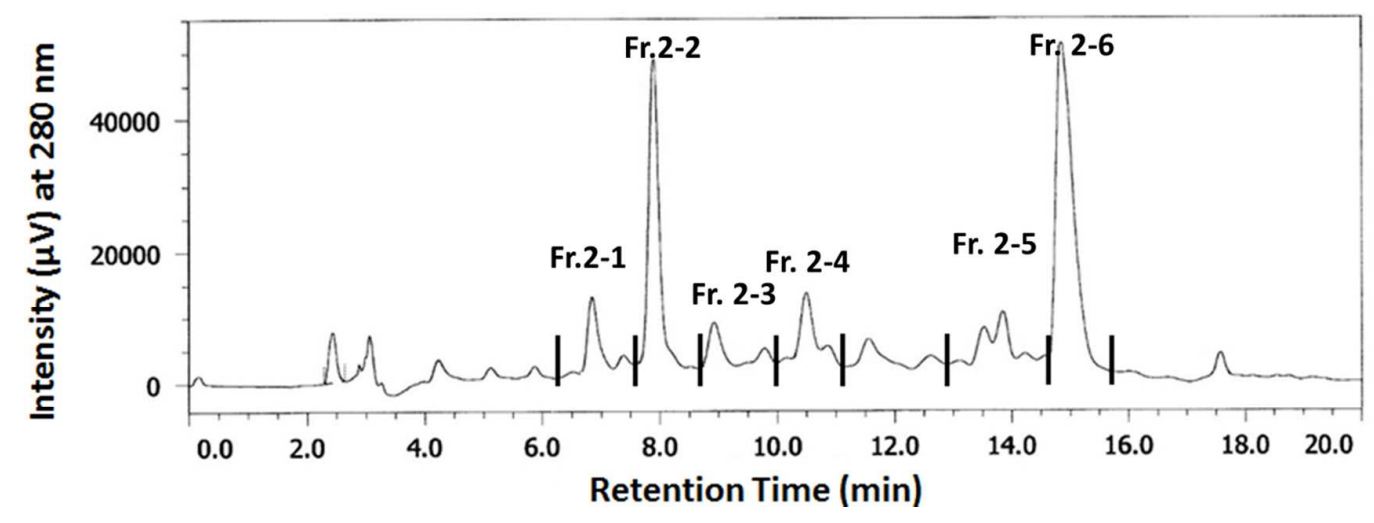

Figure 4 


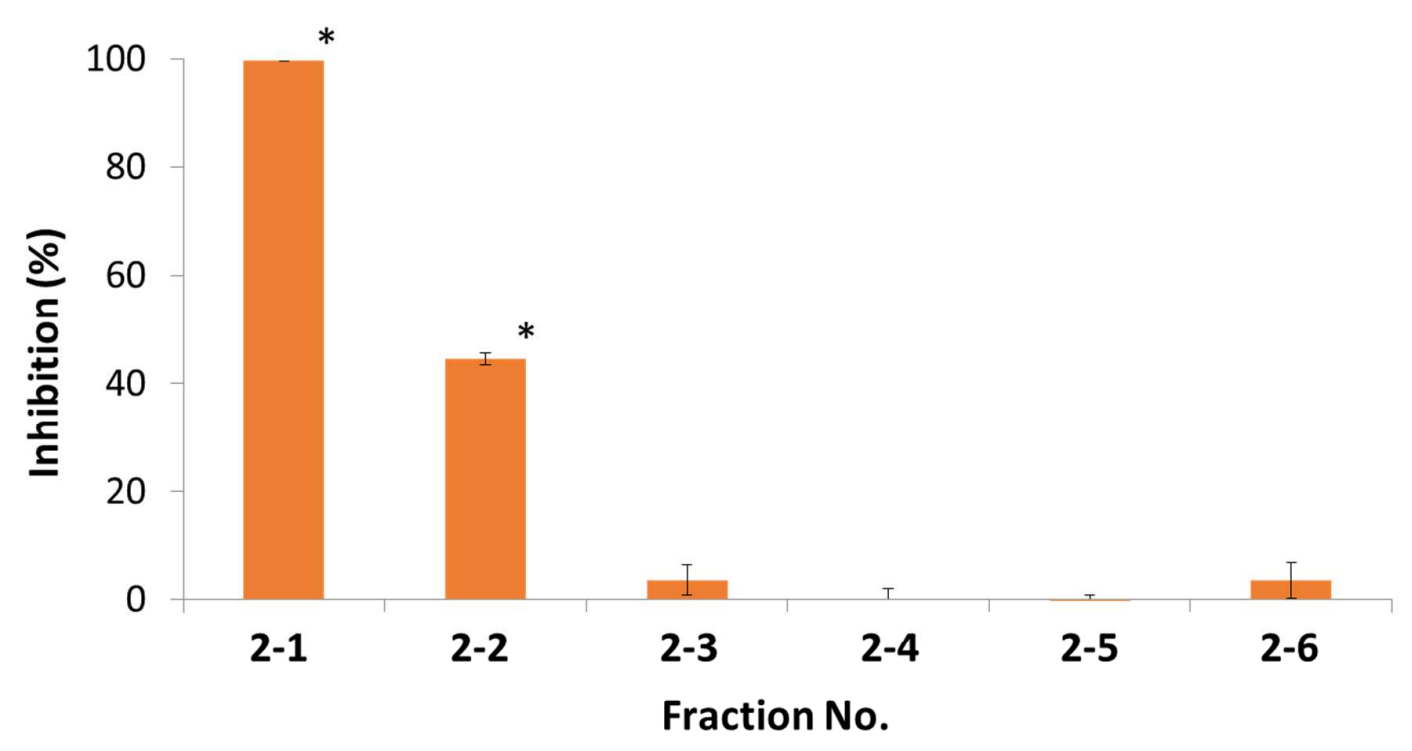

Figure 5 

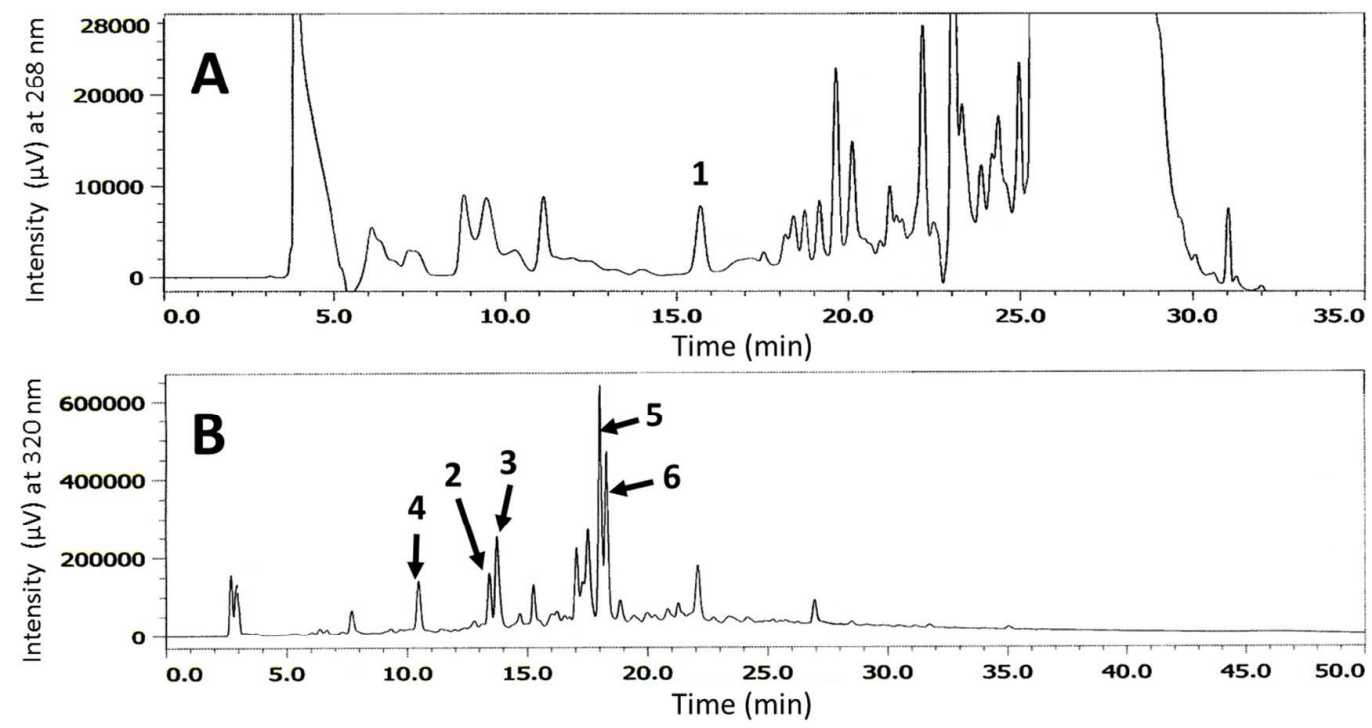

Figure 6 


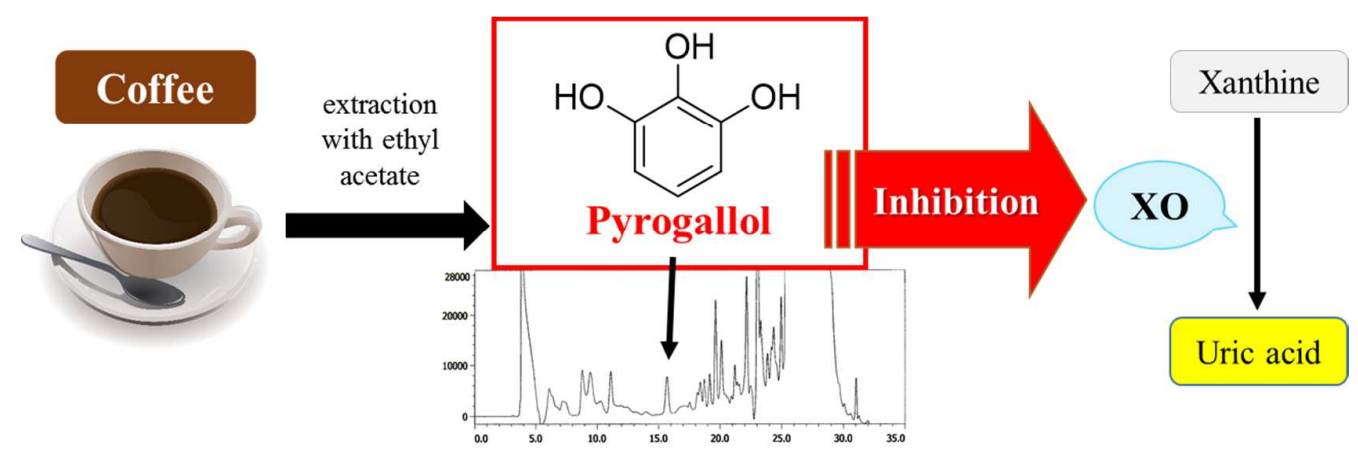

TOC Graphic Abstract 
<smiles>Oc1cccc(O)c1O</smiles>

Pyrogallol (1)<smiles>[R20]C1CC(O)(C(=O)O)CC([R20])C1[R20]</smiles>

5-O-Caffeoylquinic acid (2) $\mathrm{R}_{1}: \mathrm{H}$

$\mathrm{R}_{2}: \mathrm{H}$

$\mathrm{R}_{3}$ :Caffeoyl

4-O-Caffeoylquinic acid (3) $\mathrm{R}_{1}: \mathrm{H}$

$\mathrm{R}_{2}$ :Caffeoyl $\mathrm{R}_{3}: \mathrm{H}$

3-O-Caffeoylquinic acid (4) $\mathrm{R}_{1}$ :Caffeoyl

$\mathrm{R}_{2}: \mathrm{H}$

$\mathrm{R}_{3}: \mathrm{H}$

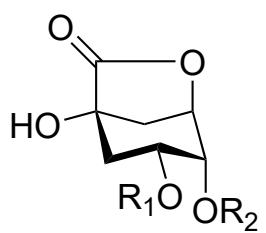

3-O-Caffeoyl-1,5-quinide (5) $\mathrm{R}_{1}$ :Caffeoyl $\mathrm{R}_{2}: \mathrm{H}$

$\mathrm{R}_{2}$ :Caffeoyl<smiles>Oc1ccc(O)c(O)c1</smiles>

1,2,4-Trihydroxybenzene (7)<smiles>Oc1cc(O)cc(O)c1</smiles>

Phloroglucinol (8)<smiles>Oc1ccc(O)cc1</smiles><smiles>Oc1ccccc1O</smiles>

$\mathrm{HO}$<smiles>Oc1ccccc1</smiles>

Hydroquinone (9) 


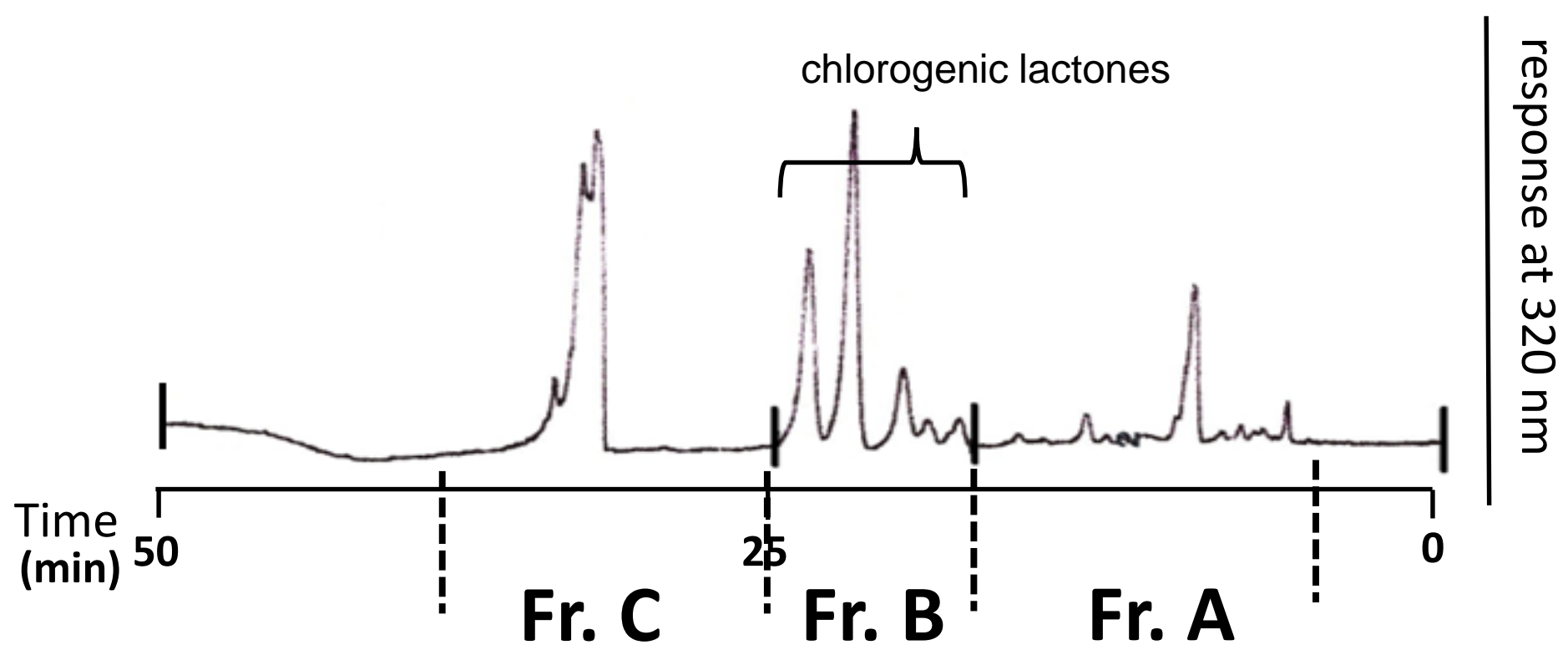




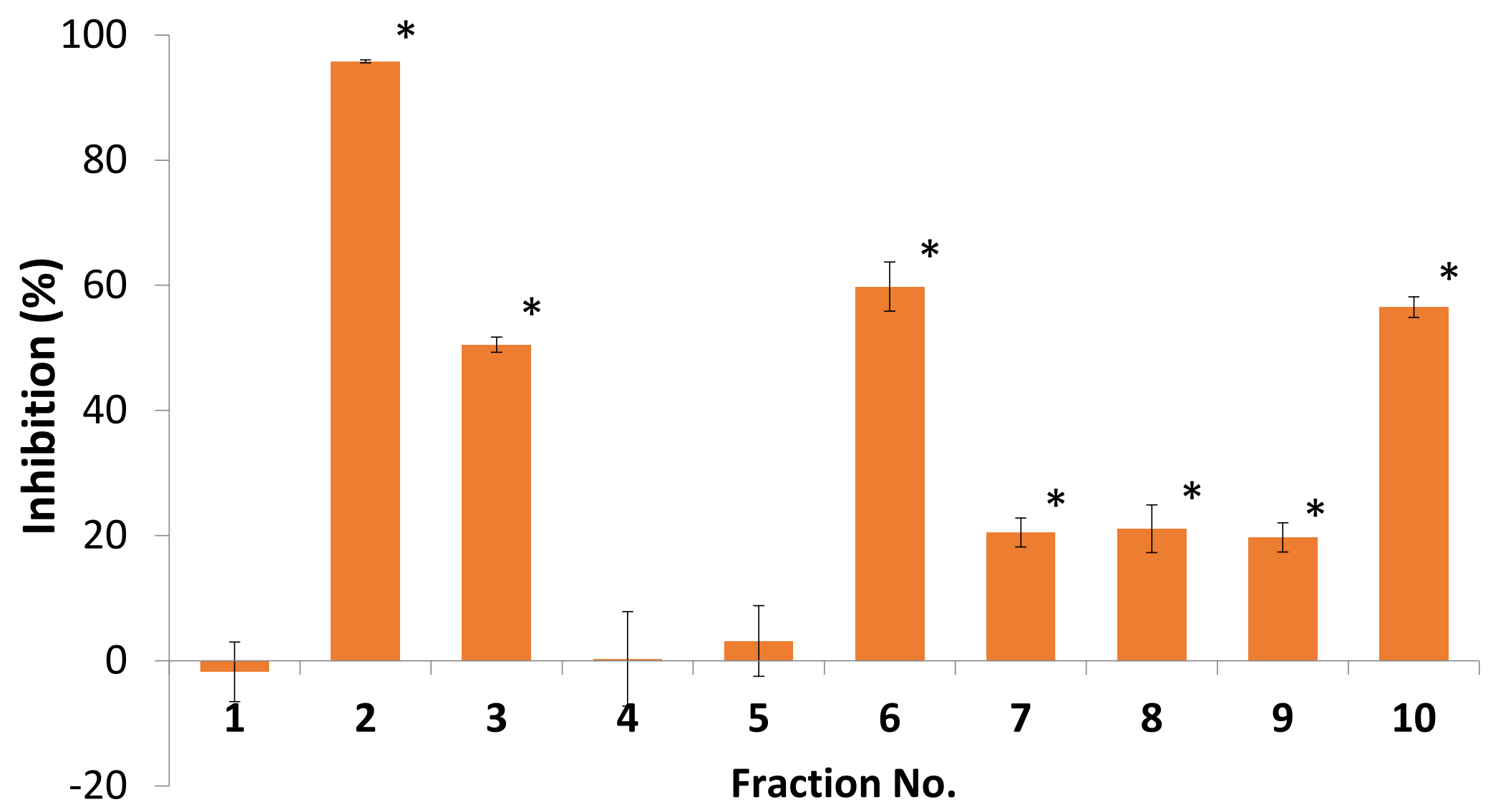




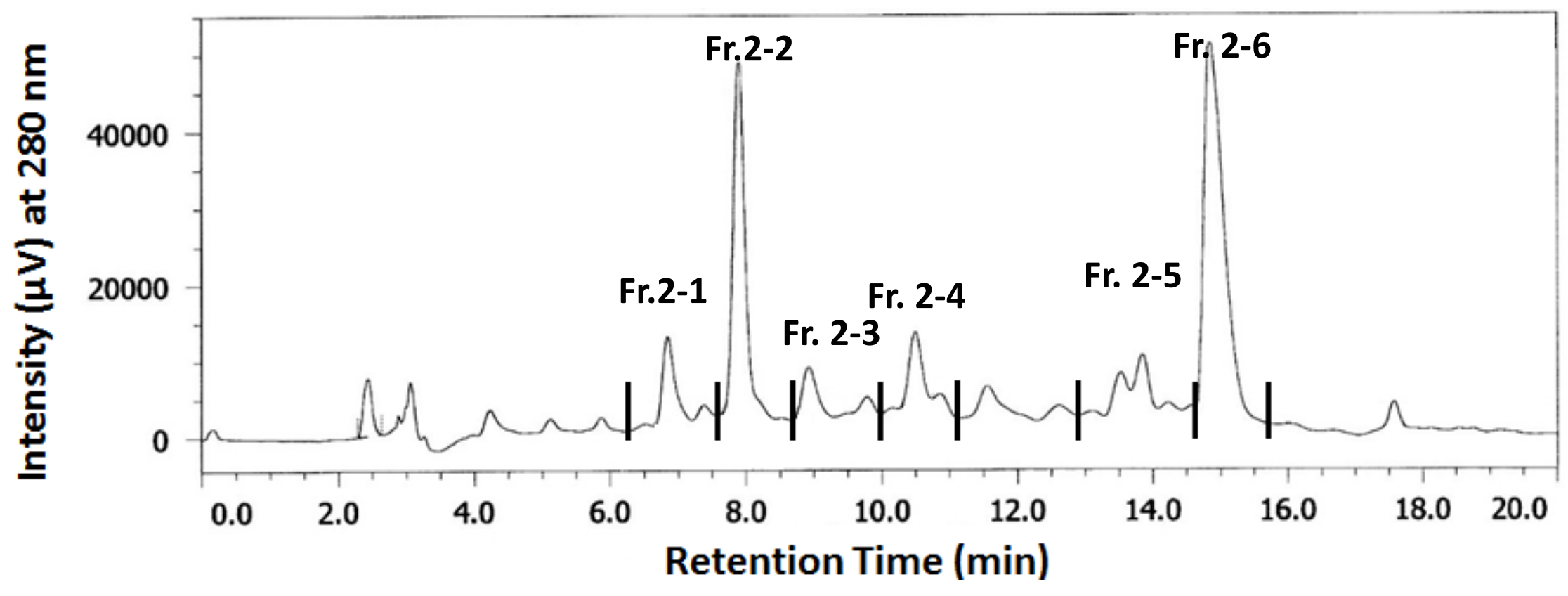

Fig. 4 


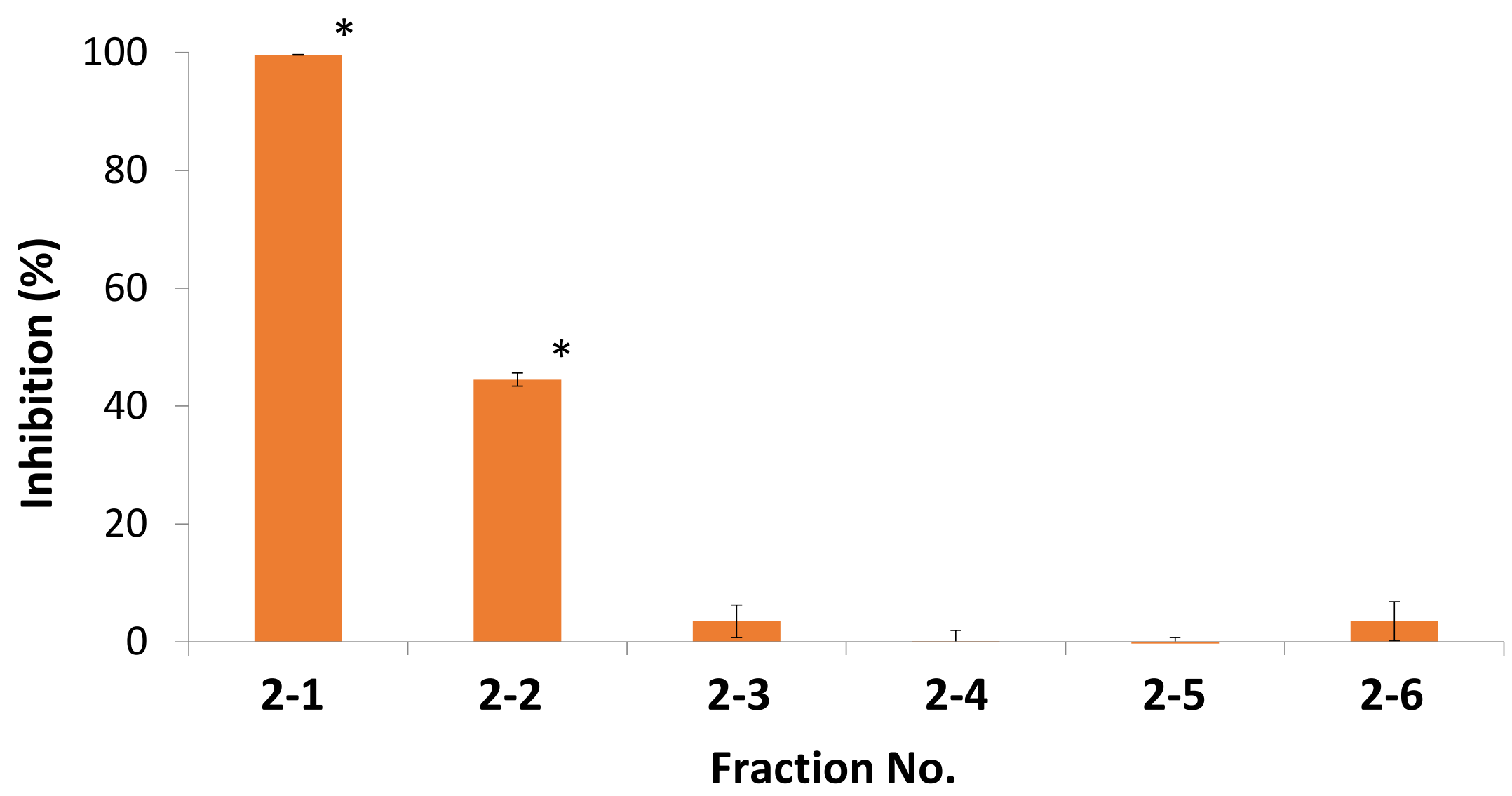



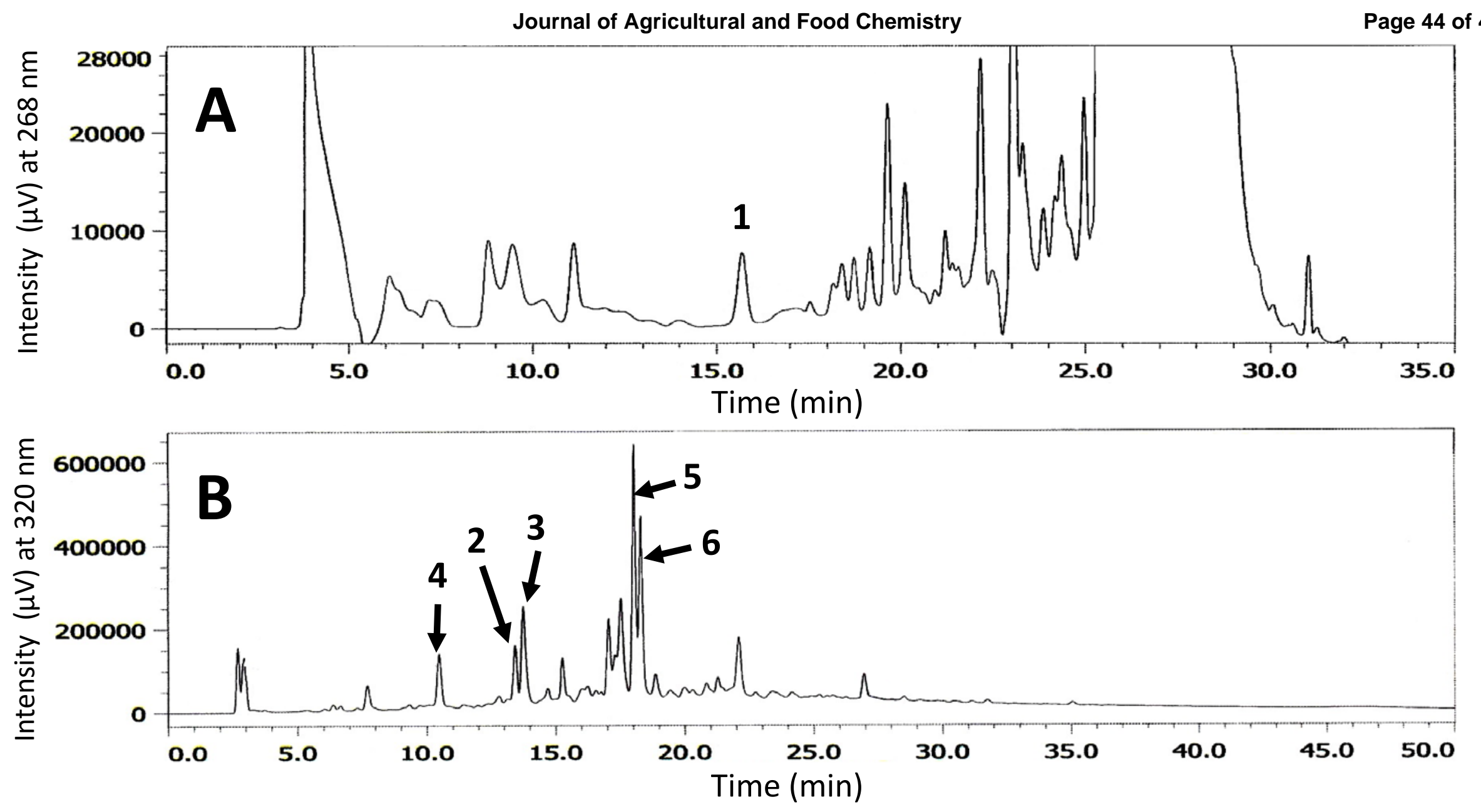


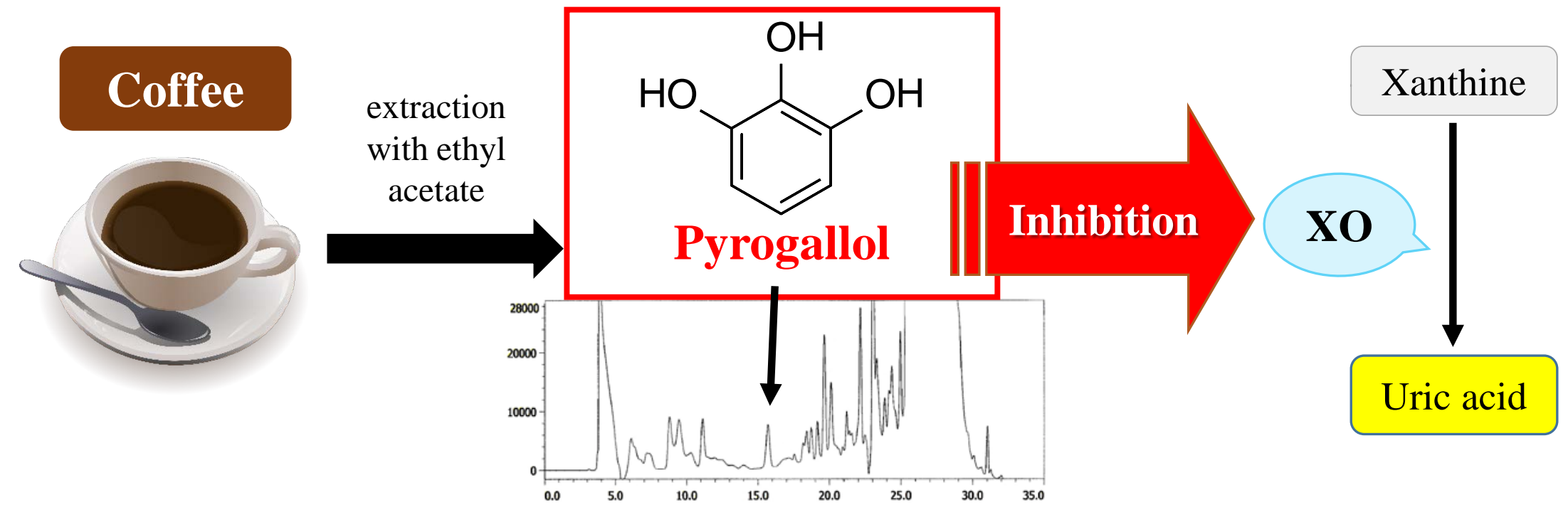

